\title{
Implementation of Curriculum 2013 Through the Department Development Program at SDIT Daarul Muttaqien
}

\author{
Lilik Hafidloh $^{1 *}$, Erny Roeminingsih ${ }^{1}$, Amrozi Khamadi $^{1}$ \\ ${ }^{1}$ Pascasarjana, State University of Surabaya, Surabaya, Indonesia \\ "Corresponding author. Email: i2kdm@gmail.com
}

\begin{abstract}
The female development program is coaching and guidance given specifically to female students whose implementation affects the implementation of the curriculum in schools. The research objectives describe and analyze the female program which includes: forms, methods and media; curriculum implementation; the impact of the female development program on curriculum implementation. Qualitative research with this type of study, with interview techniques through interviews, documentation, and participant observation. Test data wetness with credibility through triangulation of techniques and sources, transferability, dependability, and confirmability. Data analysis with condensation, presentation, and conclusions. The results showed, (1) the implementation of female development was carried out in the form of personality development through building morals and menstrual development, and building skills through building batik, weaving, embroidery, cooking, and make-up. (2) the implementation method with lectures for building morals and menstruation, counseling for menstruation development, and practice for all skill builders, (3) the media are manuals, menstrual teaching aids, batik equipment, weaving equipment, embroidery tools, make-up kits, and cooking equipment. (4) curriculum implementation with the Decree of the Foundation, integrated system, spiritual paradigm, school culture, integrated treatment, (5) impacts include: faith and obedience (KI-1), being polite and helpful (KI-2), increasing knowledge about femininity (KI-3), and creative and skilled students (KI-4). Suggestion: female training is carried out more than once a week, the menstrual development method can be done by discussing and solving problems, schools provide a special room for menstruation guidance such as a women's clinic.
\end{abstract}

Keywords: Curriculum 2013

\section{INTRODUCTION}

Education is also referred to as a series of long processes and carried out systematically in an effort to build a whole human being, both morally and spiritually, both about cognitive intelligence, afektfi, and psychomotor so that the process can form useful and dignified individuals in religious life, nation and state). Law No. 20 of 2003 on National Education System article 4 describes the principles of education implementation, among others, "education is carried out with domokratsi, fair, not discriminated against, and promotes human rights, religion, culture, and national diversity, systematic (open and meaningful), cultivating and empowering students, nudity, building willpower, developing student creativity, and implemented by utilizing all layers or components of society."[1]
The implementation of education as a forum for the formation of character and competence that is outward and inner is carried out in a structured and systematic manner by educational institutions, oriented in achieving the objectives of education nationally. To achieve it all, various steps or efforts in the realm of process have been carried out by the government from time to time. The process of implementing education by public or private education institutions or organizations is never separated from the draft program or the reference of the education program in its implementation. The design or reference is a procedure managed by each educational institution as the basis of the learning process in educational institutions or often called curriculum. Curriculum is a very important part as input for the implementation of the educational process. 
Curriculum is a draft of a learning program that is determined and that will be applied by an educational institution to support the learning process and developed based on the conditions and situation of the institution or institution of education providers (schools). For this reason, in curriculum 2013 aspects of character education get very intense attention. The intensity of character education planting in the Curriculum 2013 has been strengthened by the Presidential Regulation of the Republic of Indonesia Number 87 of 2017 on Strengthening Character Education, article 3 mentions character education carried out through the application of Pancasila values namely religious, honest, tolerant, hardworking, disciplined, creative, independent, democratic, wanting to know, nationality, love of the homeland, communicative, accomplished, fond of reading, peaceloving, environmentally minded, high-spirited, and responsible [2].

Character development of non-academic pathways in this school is actually managed in various program activities, including the practicum activities of thoharoh worship, prayer and studying, school discipline enforcement activities and most specifically through the activities of Bina Keputerian which is devoted to finalizing and strengthening the character of the nation's daughters as an important figure for the continuity of the nation going forward. The school gives very important attention to the development of the character of the princess considering that in the eyes of Islam women have an important role in coloring the life of a nation so that it needs to be strengthened character and personality early on in order to be a ptoduktif human being, tough, reliable and virtuous noble. Research from Sha'diyah explains women have a very important position in Islam [3]. Islam respects women and considers their position to be the same as that of men. Islam encourages students to be educated and have a social role in society such as in the field of politics, economy, health, and so on. Women also have a role in the care of their families, because women are leaders in the household.

Research from Tuwu in the journal Al Izzah explains "the work of women in the public sector has an impact on increasing family economic income, which strengthens the role of women in strengthening the family and state economy." [4] So it is certainly not unusual if the process of preparing tough women must be done early. Especially in the modern era and the era of advanced technology as it is today, where the tubs of two sides mature money opposite each other. On the other hand, the chances of crime and harassment are very easy to happen, while on the other hand the competition for competence in seizing opportunities and opportunities is also getting tighter. If women are not honed in their thinking skills, soft skills and personal toughness, it is not possible that the negative side of modernization and sophistication of the world of technology and information will drag them into the abyss and vice versa.
Based on the statement above, this research aims to describe and explain the form, method, and media of the program of computer development in schools; describe and explain the implementation of the 2013 curriculum in schools; and describe and explain the impact of the community development program on the implementation of curriculum in schools.

\section{METHOD}

This research uses qualitative approach which is a study to explain natural conditions where the results are described in the form of short, solid, and clear sentences. Riyanto explained that descriptive research is a research directed to explain the symptoms, facts and events regarding a condition in a particular area [5]. This qualitative research uses a type of case study where research needs to be done in depth and in great detail. Riyanto said the research with this case approach aims to learn in depth about social events that occur in individuals, groups, institutions, and communities [5]. The technique of collecting the first data of in-depth interviews by asking a few questions to the informant. Riyanto explained that the interview is a method of collecting data that requires a systematic question and answer process between researchers and informants. Second, the observation of participants is by conducting observations on all activities and events that occur at the research site [5]. Riyanto said that the observation of participants is an observation where the person who observes takes part in the life of the person being observed [5]. Third, documentation is by collecting texts, images, books, and so on obtained from research locations. Guba and Lincoln [5] explain that documents are all materials in the form of writings or films used by researchers for their research purposes.

The first data validity test with credibility test or trust test is the result of research conducted through technical triangulation and source triangulation. Engineering triangulation is a data trust test by combining several data collection techniques. Satori \& Komariah said testing data credibility by triangulating techniques is the use of various data collection techniques conducted by researchers to data sources [6]. Source triangulation is a data trust test by matching research data from other sources sat uke sources. Satori \& Komariah said that the way to increase confidence in the results of research can be done by looking for data from various sources that are interconnected with each other [6]. Both tests of transferability by summary, on, and clear the results of the study. Satori \& Komariah explained the results of the study said transferability when research reports made by researchers can provide very clear, complete, and systematic information [6]. If a reader gets a clear picture or view of the results of the research, then it meets transferability standards. The three dependency tests are the consistention of test conducted through an audit from 
an audit expert (in this case a research supervisor). Stainback [6] explained the results of a reliabel study related to the degree of consistentness and stability of the research results. So it can be called also below this test is a test of research results data where the source and technique show a high rationality. Do not let the data obtained are not traced how to get it as well as the person who revealed it. The four confirmation tests are tests on the data of research results conducted by confirming the data source (informant) so that the data obtained is not much different from the informant. Satori \& Komariah explained that a study is said to have a high degree of objectivity if the existence of data can be traced definitively and the research is said to be objective when the results of the study have been agreed by the public [6].

Data analysis techniques with condensation, data presentation, and inference. The first condensation is Sugiyono explaining the analysis done at the time of data collection and after data collection is done in a certain period [7]. At the time of conducting the interview, the researchers had conducted a limited analysis of the answers interviewed. Both presentations of data are displaying data from research in the form of writings or sentences, images, tables, and so on. Sugiyono said in qualitative research the presentation of data can be done in the form of briefs, charts, relationships between categories, flowcharts, and the like [7]. The third draw conclusion is to take the essence of the research results. Riyanto said that making conclusions about the activities took the essence of the data that had been collected during the research into a short and clear sentence statement [8]. The grids in this study can be seen in the following table:

The design of this research can be described as follows:

Table 1. Research Grid

\begin{tabular}{|c|c|c|}
\hline Aspects & Sub-Aspects & Indicators \\
\hline \multirow[t]{3}{*}{$\begin{array}{l}\text { Computer } \\
\text { Development } \\
\text { Program }\end{array}$} & Form of Activity & $\begin{array}{l}\text { 1. Able to explain the form of Bina Keputerian activities in optimizing the } \\
\text { implementation of curriculum } 2013 \\
\text { 2. Able to explain who are the mentors who carry out the Bina Keputerian } \\
\text { program in each form of activities } \\
\text { 3. Being able to explain the final objectives of each activity program for } \\
\text { the school. }\end{array}$ \\
\hline & Method of Activity & $\begin{array}{l}\text { 1. Able to explain the method of Bina Keputerian activities in each activity } \\
\text { 2. Able to explain how the method or technique is implemented }\end{array}$ \\
\hline & $\begin{array}{l}\text { Media or Tools } \\
\text { Activities }\end{array}$ & $\begin{array}{l}\text { 1. Able to explain the media or tools used for each of the Activities of The } \\
\text { Ministry of } \\
\text { 2. Able to explain how to use or use the media or tools used in each activity }\end{array}$ \\
\hline $\begin{array}{l}\text { Curriculum } \\
\text { Implementation } \\
2013\end{array}$ & $\begin{array}{l}\text { Implementation of } \\
\text { curriculum } 2013 \text { in } \\
\text { schools }\end{array}$ & $\begin{array}{l}\text { 1. Able to explain the implementation / implementation of curriculum } 2013 \\
\text { in schools } \\
\text { 2. Able to explain the results of curriculum implementation in } 2013 \text { in } \\
\text { schools (generally in schools) } \\
\text { 3. Able to explain the impact of curriculum implementation in } 2013 \text { limited } \\
\text { to the education process in schools }\end{array}$ \\
\hline Impact & $\begin{array}{l}\text { The impact of the } \\
\text { Keputerian } \\
\text { Development program } \\
\text { is limited to the } \\
\text { implementation of the } \\
2013 \text { curriculum }\end{array}$ & $\begin{array}{l}\text { Able to explain the results and impacts of the Keputerian Development } \\
\text { program is limited to optimizing the implementation of the } 2013 \text { curriculum } \\
\text { in schools }\end{array}$ \\
\hline
\end{tabular}




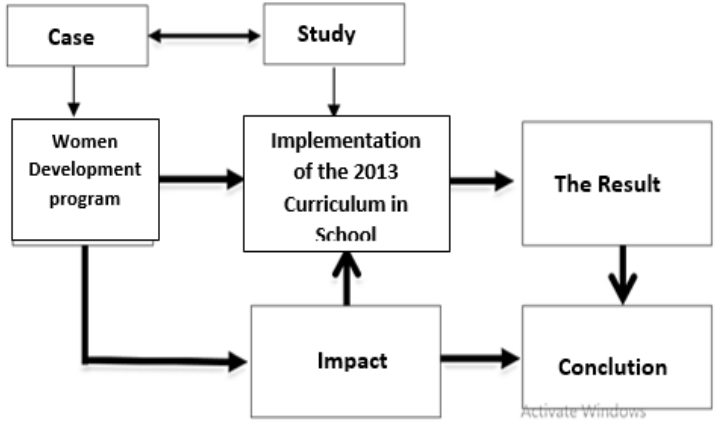

\section{RESULTS AND DISCUSSION}

The results of the study are data collected or obtained by researchers through various research techniques (interviews, documentation, and observations) during the research process. The data of research results on curriculum implementation through thisputrian development program can be displayed into the matrix of research results table as follows:

Figure 1. Research Design

Table 2. Research Grid

\begin{tabular}{|c|c|c|}
\hline No. & Focus & Research Findings \\
\hline \multirow[t]{4}{*}{1} & $\begin{array}{l}\text { Implementation of } \\
\text { Puterian } \\
\text { Development }\end{array}$ & $\begin{array}{l}\text { Activities to foster and guide students in school with the aim of providing experience, } \\
\text { knowledge and skills either hard skills or soft skills }\end{array}$ \\
\hline & $\begin{array}{l}\text { a. Form of Computer } \\
\text { Development } \\
\text { Program }\end{array}$ & $\begin{array}{l}\text { Personality building group consisting of: Bina Adab/Akhlaq and Bina Menstruasi } \\
\text { Skill Building Group consisting of: Batik,, Weeping,, Embroidery,, Tata Boga, and } \\
\text { Makeup }\end{array}$ \\
\hline & $\begin{array}{l}\text { b. Method of } \\
\text { Implementation of } \\
\text { Kepuetrian } \\
\text { Development } \\
\text { Program }\end{array}$ & $\begin{array}{l}\text { Implementation method can be explained as follows: lecture method used on } \\
\text { adab/akhlaq and menstrual development, Counseling Method used in menstrual } \\
\text { development, and practicum method used in batik, weaning, embroidery, boga, and } \\
\text { makeup }\end{array}$ \\
\hline & $\begin{array}{l}\text { c. Media Program } \\
\text { Bina Keputerian }\end{array}$ & $\begin{array}{l}\text { Media used for computer development activities as follows: bina Adab / Akhlaq, media } \\
\text { used guidebook (material); menstrual development, material book media, dolls, } \\
\text { sanitary napkins, and menstrual cards; batik batik, the media used ink or batik dye, } \\
\text { forecloung, batik cloth, pan, small candles, and so on; weaning, media used panjalin } \\
\text { blades, bamboo, pandanus, kerta, cutting tools, woven patterns and rattan; } \\
\text { embroidery, used medium threads, needles, scissors, spreadsheets, and fabrics; tata } \\
\text { boga, media used kitchen utensils such as stoves, dishes, spoons, pans, and so forth; } \\
\text { makeup, media used makeup tools, Muslim clothes, and veils. }\end{array}$ \\
\hline 2 & $\begin{array}{l}\text { Curriculum } \\
\text { Implementation } 2013\end{array}$ & $\begin{array}{l}\text { The implementation of curriculum in } 2013 \text { is divided into the first two levels of the } \\
\text { Foundation institution level through sk permit for curriculum implementation from the } \\
\text { chairman of the Foundation. The two levels of school units with an integrated system } \\
\text { are combining the } 2013 \text { curriculum with the local curriculum (Islam), building a spiritual } \\
\text { paradigm that is instilling religious values in the educational process in schools, } \\
\text { building integrated treatments that are building cooperation between schools and } \\
\text { homes (parents), and building school culture through habituation of good habit and } \\
\text { Islamic habit }\end{array}$ \\
\hline 3 & $\begin{array}{l}\text { Impact of Limited } \\
\text { Keputerian } \\
\text { Development } \\
\text { Program on } \\
\text { Curriculum } \\
\text { Implementation }\end{array}$ & $\begin{array}{l}\text { The impact of the vocational development program is limited to the implementation of } \\
\text { the curriculum in the first school, the impact on KI-1 on the spiritual is increasing the } \\
\text { obedience and faith of students through personality building. Second, the impact on } \\
\mathrm{KI}-2 \text { on attitudes is that students have a good manners and manners in speaking and } \\
\text { behaving. Third, the impact on KI-3 on knowledge is the increasing knowledge of } \\
\text { students, especially knowledge about femininity that is not obtained in academic } \\
\text { classes. Fourth, the impact on KI-4 on skills is that students are more creative and } \\
\text { have good skills based on the skills they follow. }\end{array}$ \\
\hline
\end{tabular}




\subsection{Implementation of women Development}

Bina Keputerian program is a coaching and guidance activity that is given specifically by the school to students in the school with the aim of providing experience, knowledge and skills either hard skills or soft skills specifically in the field of femininity in accordance with the teachings of Islam. Mustari explained that in student management is a service devoted to organizing, supervising and serving students in the classroom and outside the classroom such as developing students' interest until they can and are able (mature) in school [9]. In line with the statement, Kholifah, Nasution, \& Basri in Ta'dibi journal explained that the education of the princess is an educational or teaching activity carried out to change the nature, behavior, and personality of a princess [10].

\subsubsection{Body Building Shape}

The form of a computer development program is a type or type of coaching program used by a person or organization to foster women. Bina Keputerian program is divided into two areas ofthe group, namely the field of personality to organize the personality of students in order to become a true Muslimah in outner and inner, and kelompk field of skills to provide skills or handicrafts especially handicrafts to students. This computer development activity is carried out once a week in accordance with the schedule that has been determined by the school. Lestari in Untirta Civic Education Journal in his research stated that extracurricular activities aim to develop the character, talent, and citizenship skills of students both in groups and individuals [11]. Rahman that form of self-development activities can be through counseling services that include learning difficulties, personal life and social life of a person [12]. Dhuhani in Jurnal Fikratuna pesantren activities against santri is carried out by coaching, nurturing, and education to students to deepen religious knowledge [13].

The first program of women's development field or personality building group consisting of attitude or adab treatment activities is by providing knowledge about the procedures of acting, speaking, and socializing in the environment in accordance with Islamic religious; and menstrual development activities that provide knowledge about mesntruasi and how to purify themselves from menstruation. The program is in accordance with the results of research from Kholifah, Nasution, \& Basri in the journal Ta'dibi stated that ta'lim activities carried out every Friday are carried out by discussing human adap in daily life [10].

Both groups or development fields consisting of batik activities, by teaching and equipping students how to make and produce good batik; embroidery activities, namely by teaching and equipping students on how to make and produce good and neat embroidery; weaning activities, by teaching and equipping students how to produce neat and good woven; food systemactivities are by teaching and equipping students how to make healthy food and good nutritionalvalue; and make-up activities by teaching and equipping students on how to wear makeup on the face and how to wear Islamic clothes that is covering the aurat in accordance with Islamic law. , wear an Islamic hijab or veil and wear Islamic clothing or clothing. Kompri says that the purpose of extracurricular is to improve students' abilities in the community; as a place to channel and develop students' potential and talents; to train discipline, honesty, trust, responsibility, civility and attitude, as a place to guide, direct, and train students [14].

\subsubsection{Computer Development Methods}

A method is a technique used by mentors or educators of a computer coaching program to convey material or knowledge to participants or construction objects. Implementation method of women development divided into three main methods, namely the first lecture method used for personality building activities in the field of study attitude or akhlaq and the field of study of menstruation or menstruation. Lectures are used in both fields of study because the field of personality gives or conveys more material and knowledge derived from books, hadiths, the Qur'an, and so on. As revealed by Kholifah, Nasution, \& Basri in ta'dibi journal, the results of his research mention extracurricular of women can be done by searching and delivering material, as well as by practicing [10].

Both methods of counseling or consultation methods are used for personality building activities in the menstrual field, namely by conducting consultations, discussions, and question and answer questions between students and mentors about menstruation. As explained by Yusof, Zainuddin, \& Hamdan in the journal Humanika Science, the results of his research explain that training and guidance to improve the teaching and learning process, especially in the class [15]. this means that training and guidance on curriculum changes need to be done to improve the results of the teaching and learning process in the classroom.

The three practical methods are used in skill building activities because embroidery, batik, weaning, cooking, and makeup are buildings that require practice. The practice is also used in personality building especially about menstruation by practicing how to use sanitary pads (puppet media) and clean up self-purifying. As explained by Kholifah, Nasution, \& Basri in ta'dibi journal, the results of his research stated that the practice is to give examples to students, so that students can follow everything exemplified by the mentor of activities in the order of examples of practice [10]. 
The purpose of using these three methods is to facilitate, clarify, and accelerate the understanding of students limited to the material of the computer development program that is being given or implemented. Nuryanto in The Journal of Education said that the activity is expected to be able to meet the needs of students to gain new experiences and knowledge that are beneficial for themselves for life in the future [16].

\subsubsection{Media Development}

Media is a set of equipment used by a person or group to support the work that is being or will be done. First, personality development in the field of adab / morality studies is a guidebook or material book. The two media used for menstruation are books, dolls, sanitary napkins, and menstrual cards. The three batik builders used are batik ink or dye, dipper, batik cloth, frying pan, small wax, and so on. The four constructors for embroidering the media used are thread, needle, scissors, span tools, and cloth. The five weaving coaches are panjalin blades, bamboo, pandanus, paper, cutting tools, weaving patterns and rattan. The six media culinary constructions used are kitchen utensils such as stoves, plates, spoons, pans, and so on. The seven media make-up builders used are makeup tools, Muslim clothes, and headscarves. The purpose of using the media or equipment is so that students can take advantage of the media to facilitate the implementation of the fostered program and support to produce a work in accordance with the field of female development studies that are being followed by students (santri). Kunandar explains that the principle of implementing the curriculum in education units (schools) is that students must get educational services that aim to improve, accelerate potential, enrichment through various techniques or methods, media, resources, and technology that are beneficial to the learning process [17].

\section{CONCLUSIONS}

The female development program is coaching and guidance given by special schools to female students in schools which are given in two forms of training, first personal development consisting of adap / akhalq and menstrual development, secondly skills development consisting of batik, embroidery, weaving, make-up and culinary. The implementation of the female development is carried out by using the lecture method for adapting / morality and menstrual development, counseling methods for menstruation development, and practical methods for building skills in batik, weaving, embroidery, make-up and culinary. The media used in the development of kepuetrian include books for the development of adap / morality; material books, dolls, menstrual cards, and sanitary napkins for menstruation development; threads, needles, scissors, and others for building batik; batik cloth, cloth dye, dipper, frying pan, and others for building batik; panajlin blades, bamboo, pandanus, woven patterns, and rattan for building weaving; Buffer equipment such as pans, compiers, plates, etc. for cooking; make up tools, Muslim clothes, headscarves, and so on to build make-up.

The implementation of the curriculum is the application of the national curriculum in schools which is implemented by combining the national curriculum with the school curriculum, building spiritual paradigm in the learning process, building Islamic habits (culture) in the school environment, and building collaboration with parents to control student academic and non-academic achievement. .

The impact of the female development program on the implementation of the curriculum in schools is that students increase in faith and obedience to religion which in the 2013 curriculum is reflected in KI-1, students become more polite, polite, gentle with their peers and to others which in the 2013 curriculum is reflected in KI -2, students increase in knowledge which is reflected in the 2013 curriculum at KI-3, and students increase their skills and creativity, which is reflected in the 2013 curriculum in KI-4.

\section{REFERENCES}

[1] Republic of Indonesia Law, Number 20 of 2003, about the national education system

[2] Presidential Regulation of the Republic of Indonesia, Number 87 of 2017, concerning Strengthening Character Education.

[3] H. Sya'diyah, Perempuan Dalam Perspektif Islam, In: Program Studi Pendidikan Agama Islam, Fakultas Agama Islam, Universitas Muhammadiyah Purwokerto, 2014. Retrieved from https://ipsas.upm.edu.my/upload/dokumen/IISS_02 2.pdf.

[4] D. Tuwu, Peran Pekerja Perempuan Dalam Memenuhi Ekonomi Keluarga: Dari Peran Domestik Menuju Sektor Publik, in: Jurnal Al Izzah, 13(01), 2018, pp. 63-76.

[5] Y. Riyanto, Metodologi Penelitian Pendidikan, Surabaya: SIC.3, 2010.

[6] D. Satori, A. Komariah, Metodologi Penelitian Kualitatif, Bandung: Alfabeta, 2010.

[7] Sugiyono, Metode penelitian kuantitatif, kualitatif, dan R \& D, Bandung: Alfabeta, 2010.

[8] Y. Riyanto, Metodologi Penelitian Pendidikan: Kualitatif dan Kuantitatif, Surabaya: Unesa University Pers, 2007.

[9] M. Mustari, Manajemen Pendidikan, Jakarta: Raja Grafindo Persada, 2014. 
[10] S. Kholifah, S. A. Nasution, and H. Bisri, Pendidikan Keputrian Dalam Pembentukan Kepribadian Muslimah yang Terampil, in: Ta'dibi, 5(April), 2016, pp. 34-43.

[11] R. Y. Lestari, Peran Kegiatan Ekstrakurikuler Dalam Mengembangkan Watak Kewarganegaraan Peserta Didik, Untirta Civic Education Journal, Vol. 1 No. (2), 2016, pp. 136-152.

[12] M. Rahman, Kurikulum Karakter (Refleksi dan Proposal Solusi Atas Terhadab KBK dan KTSP), Jakarta: Prestasi Pustakaraya, 2012.

[13] E. M. Dhuhani, Manajemen Pondok Pesantren; Studi Pengelolaan Santri Muallaf di Pondok Pesantren Al-Ashar Ambon, in: Jurnal Fikratuna, 09(01), 2018, pp. 54-70.

[14] Kompri, Manajemen Pendidikan: KomponenKomponen Elementer Kemajuan Sekolah, Yogyakarta: Ar-Ruzz Media, 2015.

[15] S. M. Yusof, D. S. Zainuddin, and A. R. Hamdan, Teachers' Experience in Curriculum Implementation: An Investigation on English Language Teaching in Vocational Colleges in Malaysia, in: Sains Humanika, 9(4-2), 2017, 49-58. DOI: https://doi.org/10.11113/sh.v9n4-2.1359

[16] S. Nuryanto, Manajemen Kegiatan Ekstrakurikuler di SD Al Irsyad 01 Purwokerto, in: Jurnal Kependidikan, 05(01), 2017, pp. 115-129.

[17] Kunandar, Guru Profesional: Implementasi KTSP dan Sukses dalam Sertifikasi Guru, Jakarta: Rajawali Press, 2011. 